\title{
Applying Topic Modelling to Party Discourse: An Exploration of the Italian Case in 2013-2019
}

\author{
ANDREA PARESCHI \\ andrea.pareschi2@unibo.it \\ University of Bologna
}

\begin{abstract}
During the last few years, external crises and endogenous weaknesses have combined to plunge the Italian political system into generalised instability. In particular, the major political parties have experienced rapidly turning tides in a context of intensified electoral volatility. This explorative article sets out to get an insight into the discursive struggles that have pitted these parties one against another, undergirding the ebb and flow in their respective mass support and revolving around the ways of communicating political change. To that end, I collect data from the official Facebook pages of the four main Italian parties, downloading posts they published in the period 2013-2019 via the Netvizz application, and I analyse the four corresponding textual corpora through the technique of Topic Modelling. On such bases, the article finds the overall configuration of the political discourse of Italian parties to be aptly described by a model comprising 16 topics, equally divided into 'partisan' and 'cross-cutting' ones, with the former having a slight edge in terms of diffusion. The four parties differ among themselves by the topics they focus on and by the quantity of topics they choose to include sizably in their streams of communication.
\end{abstract}

\section{Introduction}

Over the decades, multiple bodies of research in the discipline of political science have progressively shed light on the plurality of dynamics of competition among political parties aiming to obtain and maintain electoral support. Most obviously, parties vie with each other by taking different positions on broad ideological dimensions - the most traditional one in modern politics being the left-right axis (e.g., Dalton, 1985) - as well as on more specific issues, such as income equality, welfare provision, environment and energy, LGBT rights and so on. In this vein, parties' positions are expected to be rooted in strategic calculus that factors in the spatial distribution of the preferences of the electorate (Downs, 1957). Important as it surely is, however, position-taking is not the end of the story.

In fact, struggles in the party system also take place in the shape of contests over issue salience (Budge and Farlie, 1983), that is, the relative centrality of different issues in political discourse and in the eyes of citizens. What is continuously at stake is the very structure of inter-party competition (Rovny, 2012; Rohrschneider and Whitefield, 2012), as each political force talks past the others in order to boost the importance of the issues where its stances may resonate the most with the electorate. Relatedly, opportunities for a party to take advantage of the salience of an issue are predicated on the reputation that citizens attribute to the said party in 
relation to the handling of that issue. If a party has managed to achieve 'issue ownership' (Petrocik, 1996) in a policy domain, it may also strive to leverage the issue it 'owns' by framing other issues in tailored ways that tie them to it. Populist radical right parties, for instance, often endeavour to frame (in)security as having a direct linkage to immigration - or to subsume stances towards the EU under the same culturally conservative bundle (Hoeglinger, 2016).

All these insights corroborate the argument whereby much of the competition among political forces occurs within and through public discourse. As "the social world is [...] a kaleidoscope of potential realities, any of which can be readily evoked by altering the ways in which observations are framed and categorized" (Edelman, 1993: 232), political actors are deeply invested in 'framing contests' in which they engage by releasing continuous streams of communication that create, modify and sustain political meanings, as regards the centrality of various events and phenomena and the ways in which they should be interpreted (Gamson and Modigliani, 1989). Accordingly, mass communication scholars refer to strategies of 'agenda-setting' and 'priming', in addition to 'framing' (Chong and Druckman, 2007). Normative theories of democratic representation, by the way, have recently rediscovered and revalued the influence exerted by political elites over the public opinion: "to find politicians framing, cueing, and priming, and to find citizens forming preferences in response to that activity, is merely to find both exercising the practice of representation, understood in the iterative sense" (Disch, 2011: 109).

One context where the discursive clashes among parties have acquired special relevance and interest is the case of Italy during the 'critical juncture' of the past few years. Over the last decade, Italy has borne the brunt of two crises that have asymmetrically hit Europe: the sovereign debt crisis and the so-called migrant crisis. The ensuing predicaments have added to pre-existing ailments, contributing to a spiral of political instability in the country. Ever since 2010, no less than seven governments have come in succession, including a governo tecnico and, most recently, two cabinets of very different political colour led by the same individual. The credentials of the erstwhile established parties of the centre-left and centre-right have been maimed, opening up opportunities for fierce challengers such as the Five Star Movement and Matteo Salvini's rebranded League, which have attracted much scholarly attention (e.g., Passarelli and Tuorto, 2018; Mosca and Tronconi, 2019). Their recent experience with the challenge of government has added yet another tile to the unstable trajectory of the Italian party system, where dramatic change was epitomised by extremely high volatility indexes on the occasion of the 2013 and 2018 general elections.

Against this background, I set out to get an insight into the discursive struggles, involving the main Italian parties and revolving around ways of communicating political change, that have undergirded the dramatic ebb and flow in their respective electoral support. On the basis of a general interest in the language, categories and narratives that have entered the realm of public discourse and collided within it, this explorative article addresses a more clear-cut question considering which topics have been widespread within political discourse in recent years. Empirically, I tackle this issue by focusing on the streams of political communication of the four most important political parties of Italy over the period 2013-2019. Specifically, data collection was based on the download of Facebook posts from the official pages of such parties, both for the sake of straightforward comparability and because social media are increasingly regarded as crucial outlets for political communication (e.g., Ernst et al., 2017). The textual evidence was then processed by means of Topic Modelling, a semi-automated technique for 
text analysis that permits dealing with large corpora of text, while at the same time preserving the power of induction.

In a nutshell, this article finds the overall configuration of the political discourse of the main Italian parties between 2013 and 2019 to be adequately described by a model comprising 16 topics. These topics are equally divided into two groups: the first type is marked by a partisan nature, in that such topics visibly refer to the communication of specific parties, whereas the second type is marked by a cross-cutting nature, as such topics are defined by thematic, programmatic and policy-related words. In terms of presence within the textual corpora as a whole, topics of the former type are found to prevail very slightly over topics belonging to the latter, albeit the individual topics all display roughly comparable frequencies of usage. At the party level, the 'voices' of all four political forces are characterised in the first place by recourse to the partisan topics that inform their respective styles of communication, and only in the second place by emphasis on cross-cutting issues and policy domains. The parties differ among themselves not only by the specific issues they focus on, but also by the extent to which they target head-on a few topics, as opposed to discussing many of them in a more extensive but also diluted perspective.

The paper is structured as follows. In the following section, I present in greater detail the dataset employed and the methods of analysis, that is, Topic Modelling. The third section, devoted to the presentation and discussion of results, unfolds in multiple sub-sections. It deals at first with the outcomes of the application of Topic Modelling to the textual corpora, elucidating the individuation of the most suitable topic model and the identification of its 16 topics. It then accounts for the diffusion of each topic among the overall textual corpora, also providing a year-by-year breakdown. Finally, it performs a party-level analysis by highlighting how much each topic is invoked by each one of the relevant parties, as well as how much each party's discursive menu relies on each one of the various topics. The final section draws conclusions on the findings and limitations of the study, together with possible future pathways.

\section{Data and methods}

Within this study, I focus on the discourse of Italian political forces as it was articulated and disseminated in 2013-2019 by the four main parties of the Italian party system. Undoubtedly, the Democratic Party (Partito Democratico, PD), the Five Star Movement (Movimento 5 Stelle, M5S), Forward Italy (Forza Italia, FI) and the (Northern) League (Lega Nord) were the dominant actors throughout the considered period, although they were at times joined by minor parties having acquired relevance as per Sartori's (1976) famous criteria. Table 2.1 exhibits the recent rollercoaster in the fortunes of the major parties.

\begin{tabular}{|l|c|c|c|c|}
\cline { 2 - 5 } \multicolumn{1}{c|}{} & $\mathbf{2 0 1 3} \mathbf{G E}$ & $\mathbf{2 0 1 4} \mathbf{~ E E}$ & $\mathbf{2 0 1 8} \mathbf{G E}$ & 2019 EE \\
\hline $\mathbf{F I}^{1 *}$ & $21.6 \%$ & $16.8 \%$ & $14.0 \%$ & $8.8 \%$ \\
\hline League & $4.1 \%$ & $6.2 \%$ & $17.3 \%$ & $34.3 \%$ \\
\hline
\end{tabular}

\footnotetext{
${ }^{1}$ Berlusconi's party ran the 2013 general election as The People of Freedom (Il Popolo della Libertà, PdL), before embracing again its previous denomination from 2014 onwards.
} 


\begin{tabular}{|l|c|c|c|c|}
\cline { 2 - 5 } \multicolumn{1}{c|}{} & $2013 \mathrm{GE}$ & $2014 \mathrm{EE}$ & $2018 \mathrm{GE}$ & $2019 \mathrm{EE}$ \\
\hline M5S & $25.6 \%$ & $21.2 \%$ & $32.7 \%$ & $17.1 \%$ \\
\hline PD & $25.4 \%$ & $40.8 \%$ & $18.8 \%$ & $22.7 \%$ \\
\hline
\end{tabular}

Table 2.1. Parties' electoral support (\%) in general elections and European elections in Italy, 2013-2019.

In principle, the discourse crafted and propagated by political parties during a given period could be traced and analysed on the basis of multiple sources of empirical data. Alternative options include - but are not limited to - party statements and communiqués, news reports gathered by press agencies, newspaper articles or TV newscasts, leaders' speeches, parliamentary debates, official Twitter and Facebook accounts (Bottos, Desiata and Pareschi, 2020). While the respective pros and cons of these alternatives cannot be summarised here, resorting to the official Facebook pages of the parties themselves arguably constitutes both a promising and a relatively uncharted option. In fact, just like the traditional media, the social media offer "a site on which various social groups, institutions, and ideologies struggle over the definition and construction of social reality" (Gurevitch and Levy, 1985: 19).

\begin{abstract}
Fan pages, specifically, reflect the ways in which organisations and agents wish to portray themselves to citizens. In other words, they work as identity mechanisms, embodying the constitutive messages, narratives and ideas through which the political actors are willing to position themselves within the public debate and the electoral market. Like party manifesto statements, the statements propagated through Facebook fan pages reflect both ideological and strategic considerations, gauge both issue positions and issue salience, and present unmediated party voices. At the same time, the Facebook page of a party provides continuous interpretation and stance-taking on external events, also allowing variability to be detected in the discourse conveyed on given topics - precisely insofar as the party itself wishes to permit this, for instance by sharing comments made by multiple party figures (Bottos, Desiata and Pareschi, 2020: 42-43).
\end{abstract}

After singling out the Facebook pages of the four parties, I downloaded from each one a textual corpus composed of as many page posts as possible. Reportedly, Facebook content has an unstable nature (Behar Villegas, 2016): in relation to this, the usage of an automatic tool has been found to lead to more limited loss of data than a manual approach to retrospective data collection. Consequently, for the purpose of data gathering I relied on the Netvizz application (Rieder, 2013). Netvizz is an extraction tool designed to work through Facebook's Application Programming Interface (API), allowing to retrieve a maximum of 600 posts per year - with a notable exception I immediately go on to point out.

Such data collection yielded an overall amount of 16,841 published posts: 4,577 for the League, 4,255 for M5S, 4,210 for PD and 3,799 for FI. The Table below reports the exact amount of downloaded page posts per party and per year. Admittedly, the party discourse of 2019 enjoys a slight over-representation within the textual corpora. In fact, while the data was downloaded after the first six months of 2019 - one month after the European elections - the mentioned 600-post upper threshold does not appear to be in place for the gathering of posts published during the year when the download is carried out. In theory, it would have been easy to redress the asymmetry by downloading the data again in 2020, to avoid any possible selection bias. However, in late 2019 - as a result of the Cambridge Analytica scandal - 
Facebook gave a sweeping turn of the screw to access to its data, which sounded the death knell for Netvizz and rendered any further download unattainable. While this is unfortunate, il faut faire avec.

\begin{tabular}{|l|c|c|c|c|c|c|c|r|}
\cline { 2 - 9 } \multicolumn{1}{c|}{} & $\mathbf{2 0 1 3}$ & $\mathbf{2 0 1 4}$ & $\mathbf{2 0 1 5}$ & $\mathbf{2 0 1 6}$ & $\mathbf{2 0 1 7}$ & $\mathbf{2 0 1 8}$ & $\mathbf{2 0 1 9}$ & Total \\
\hline FI & 342 & 595 & 600 & 597 & 335 & 538 & 792 & 3,799 \\
\hline League & 599 & 595 & 600 & 599 & 594 & 598 & 992 & 4,577 \\
\hline M5S & 450 & 600 & 588 & 594 & 599 & 579 & 845 & 4,255 \\
\hline PD & 587 & 499 & 593 & 593 & 593 & 592 & 753 & 4,210 \\
\hline
\end{tabular}

Table 2.2. Facebook page posts downloaded and included in the analysis, per party/per year.

I analysed the data in consecutive stages, as is detailed in the remaining part of this section. First, I developed a so-called 'stopword list', that is, a list of the words that should be excluded a priori from any automated content analysis to be performed by a software, since they do not convey any substantive meaning (e.g., articles, prepositions, adverbs, and the like). Constructing the stopword list was a preliminary procedure, instrumental in 'cleaning' the dataset. After the stopword list had been assembled and implemented, which resulted in the exclusion of the words it contained, the four textual corpora corresponding to the Italian parties comprised a grand total of 346.093 words, whereas the longest post was composed of 1.133 words.

Second, in order to obtain an introductory snapshot of the recurring political message respectively produced and propagated by each party in its online communication, I carried out a simple word count. Although it does not provide polished results, word count is quite effective as a first, explorative approach to the content of a textual dataset. Accordingly, a separate word count was executed for each one of the four textual corpora separately. To this end I relied on the software NVivo, by means of which which I then crafted for each party a 'word cloud', reflecting in a visually accessible manner the universe of signifiers evoked by that party in its streams of communication.

The main part of the data analysis then took place, by sifting the whole of the textual corpora through the semi-automated text analysis technique known as Topic Modelling (Blei et al., 2003). Based on an algorithm called Latent Dirichlet Allocation, Topic Modelling works by placing words that often co-occur together into an array of topics, consequently defined by their nature as sets of meaningful words (Mohr and Bogdanov, 2013). While dealing with large corpora of texts and producing explicit and reproducible results, Topic Modelling can also deal with polysemy, that is, the fact that the same word can be endowed with different meanings in different contexts (DiMaggio, Nag and Blei, 2013). I performed Topic Modelling through the state-of-the-art software MALLET (McCallum, 2002). For the purpose of processing the textual evidence, each individual Facebook post was treated as a unit of analysis. Based on the outcomes of the analysis, every post pertaining to the textual corpora would come to be conceptualised anew as a mix of the topics identified within it.

When Topic Modelling is deployed to analyse textual data, the software sorts all the words contained in the dataset into a variety of different topics. However, to clarify how this technique works in practice, I must point out a few basic elements. First, per se such topics 
correspond to 'boxes', only defined by the sets of words respectively associated with them, so that it falls on the researcher to grasp ex post the meaning of each topic. Second, the actual number of topics to be isolated by the automated part of the analysis must be specified prior to the analysis itself. As a result, multiple solutions - i.e., multiple topic models - are possible: one solution exists for every number of topics one may wish the Topic Modelling process to yield. In spite of these thorny aspects, the final stage of the analysis must entail the inductive identification of a solution deemed to be the most suitable one, a solution composed of an array of topics each one of which should be represented by a clear-cut, cohesive core meaning.

To that end, the three key outputs of the Topic Modelling algorithm have to be aptly exploited. They are: (i) a list of the words defining each topic, in descending order of importance; (ii) a source per topic matrix, mapping the composition of each unit of analysis in terms of topics; (iii) a word per topic matrix, specifying the coding of each word comprised in the textual corpora. Firstly, then, a researcher must specify a figure, corresponding to the number of topics which will be constructed by the automated procedure. Secondly, after such procedure has been carried out, she is compelled to reason inductively on the basis of the mentioned outputs, seeking to unveil the core meaning that lies behind each topic. Thirdly, she must repeat this process for every potentially suitable number of topics to be discovered, in order to be able to compare and contrast the various possible solutions. At the end, a decision on the most adequate solution shall be made, consistent with criteria proposed by the literature or specified beforehand in line with the research goals.

As is imaginable, the inductive stage of Topic Modelling shares with other forms of qualitative and semi-qualitative text analysis a potential pitfall, namely its dependency on subjective classifications made by human operators. A standard way of addressing the issue usually goes under the name of 'inter-coder reliability'. With a view to assuaging research concerns as soundly as possible, I entrusted a second researcher with the responsibility of independently carrying out all the tasks I have just described, including both the identification of the most appropriate topic model and the description of the content of each topic. The two sets of decisions were entirely analogous.

\section{Discussion of results}

\subsection{Identification of topics}

Following standard practice (e.g., Ferri, Lusiani and Pareschi, 2018), in line with the discussion above, I originally developed different topic models including different numbers of topics. Pertinent qualitative criteria for preferring one topic model to another had been specified beforehand, including: (i) the internal coherence and ease of interpretation of each and every topic comprised by a given solution; (ii) analytical separation between different issues or policy domains (e.g., immigration and Europe), that is, their allocation to different topics in spite of any linkages promoted by the discourse of certain political actors; (iii) a higher proportion of topics corresponding to cross-cutting issues and policy domains, arguably more meaning-laden than those topics connoted by references to partisan styles of communication. As different scholars suggest a variety of qualitative and quantitative methods for selecting the 'right' number of topics (Hannigan et al., 2019), I also relied on the quality index loglikelihood/token - which is one of the outputs of MALLET - as a compass, an ancillary criterion to reinforce the qualitatively oriented ones. 
To single out the solution characterised by the highest interpretive power (DiMaggio, Nag and Blei, 2013), at first I developed topic models that respectively comprised 5, 8, 11, 14, 17, and 20 topics. Generally speaking, solutions composed of numbers of topics lower than 11 would evidently conflate distinct issues, whilst the 20-topic solution would patently split a same discursive area into multiple topics. Hence, I also ran and closely examined all models including a number of topics that ranged from 12 to 19 . The 16-topic solution, which already appeared to be the most appropriate one in view of the qualitative criteria stated above, was also the one displaying the highest log-likelihood. Hence, it proved superior to any other topic model on all counts.

After selecting this solution, the data analysis sought to achieve sound interpretation of the substantive content of each topic, thus moving to the extraction of the 16 topics from the textual corpora. In order to comprehend their respective meanings and scopes, I straightforwardly relied on two outputs of the algorithm: the inventory of the most important words characterising each topic, and the source per topic matrix detailing the composition of each Facebook post in terms of topics. The former tool - which I had already considered, for all models composed of 11-19 topics, to attain a research decision on the most appropriate solution - provided the basis for inductively developed labelling. Table 3.1.1 presents (in the original Italian language) the 30 most important words for each topic, together with an inductively moulded label reflecting its essence. 
punt(Oorg

\begin{tabular}{|c|c|c|c|c|c|c|c|}
\hline Topic 1 & Topic 2 & Topic 3 & Topic 4 & Topic 5 & Topic 6 & Topic 7 & Topic 8 \\
\hline $\begin{array}{l}\text { Government and } \\
\text { Economy }\end{array}$ & M5S Participation & $\begin{array}{l}\text { Socioeconomic } \\
\text { issues }\end{array}$ & League events & $\begin{array}{c}\text { PD } \\
\text { Communication }\end{array}$ & European Union & $\begin{array}{l}\text { Employment } \\
\text { Schools } \\
\text { Development }\end{array}$ & FI Communication \\
\hline governo & stelle & euro & salvini & partito & europa & lavoro & italia \\
\hline lavoro & movimento & cittadini & matteo & matteo & italia & scuola & forza \\
\hline tasse & italia & milioni & piazza & democratico & europea & sviluppo & renzi \\
\hline imprese & cittadini & italiani & roma & diretta & contro & territorio & governo \\
\hline miliardi & roma & lavoro & Milano & renzi & europeo & italia & brunetta \\
\hline economia & donazione & reddito & domenica & nazionale & paesi & locali & più \\
\hline fiscale & rousseau & soldi & sabato & http://goo.gl & stati & programma & gasparri \\
\hline crescita & portavoce & cittadinanza & domani & politica & italiano & mondo & conclude \\
\hline renzi & parlamento & banche & dicembre & zingaretti & bruxelles & cultura & dichiara \\
\hline euro & settembre & legge & incontro & cover & politica & opere & afferma \\
\hline paese & cambiamento & stato & referendum & photo & europei & infrastrutture & matteo \\
\hline disoccupazione & massimo & lavoratori & capitano & nicola & paese & giovani & nota \\
\hline aumento & politica & miliardi & stampa & scuola & guerra & ricerca & camera \\
\hline bilancio & diretta & famiglie & sindaco & orenove & terrorismo & sicurezza & presidente \\
\hline italiani & aspettiamo & decreto & sera & martina & italiana & ambiente & gelmini \\
\hline manovra & partiti & pensioni & settembre & maurizio & internazionale & ministro & bergamini \\
\hline crisi & bisogno & governo & festa & intervista & libertà & grandi & aggiunge \\
\hline istat & sostieni & stipendi & pontida & roberto & mondo & nazionale & capogruppo \\
\hline debito & piccola & contro & iovotono & segui & unione & servizio & renato \\
\hline posti & luigi & risparmiatori & diretta & democratica & francia & rifiuti & scrive \\
\hline $\mathrm{imu}$ & rimini & povertà & popolo & unità & popolo & salute & premier \\
\hline decreto & vediamo & dare & bologna & sito & parlamento & futuro & responsabile \\
\hline
\end{tabular}


punt(Oorg

\begin{tabular}{|c|c|c|c|c|c|c|c|}
\hline Topic 1 & Topic 2 & Topic 3 & Topic 4 & Topic 5 & Topic 6 & Topic 7 & Topic 8 \\
\hline $\begin{array}{l}\text { Government and } \\
\text { Economy }\end{array}$ & M5S Participation & $\begin{array}{c}\text { Socioeconomic } \\
\text { issues }\end{array}$ & League events & $\begin{array}{c}\text { PD } \\
\text { Communication }\end{array}$ & European Union & $\begin{array}{l}\text { Employment } \\
\text { Schools } \\
\text { Development }\end{array}$ & FI Communication \\
\hline investimenti & contributo & dignità & live & terrazzapd & russia & lavori & maurizio \\
\hline famiglie & futuro & minimo & manifestazione & andrea & regole & qualità & deputata \\
\hline pil & maio & parlamentari & aspettiamo & formazione & uniti & nuovo & deputati \\
\hline conti & importante & banca & gazebo & segretario & cambiare & scuole & savino \\
\hline economica & palermo & vitalizi & stefano & italia & immigrazione & fondi & senatore \\
\hline iva & vogliamo & migliaia & ragioni & festa & parole & università & carfagna \\
\hline mesi & raggi & pensione & cittadinanza & emanuele & solidarietà & tav & squeri \\
\hline $\operatorname{tax}$ & evento & imprese & verona & www.beppegrillo.it & stato & nuove & palazzo \\
\hline
\end{tabular}

\begin{tabular}{|c|c|c|c|c|c|c|c|}
\hline Topic 9 & Topic 10 & Topic 11 & Topic 12 & Topic 13 & Topic 14 & Topic 15 & Topic 16 \\
\hline Justice and rights & $\begin{array}{c}\text { M5S } \\
\text { Dissemination }\end{array}$ & $\begin{array}{l}\text { Centre-right } \\
\text { coalition }\end{array}$ & Immigration & $\begin{array}{l}\text { Elections and the } \\
\text { League }\end{array}$ & $\begin{array}{c}\text { Central } \\
\text { institutions }\end{array}$ & League media & Politics as hope \\
\hline stato & http://bit.ly & berlusconi & lega & lega & legge & lega & paese \\
\hline giustizia & video & italia & nord & domenica & senato & salvini & governo \\
\hline commissione & maio & forza & video & vota & camera & streaming & politica \\
\hline forze & diffondete & presidente & roma & voto & governo & hashtag & stato \\
\hline sicurezza & luigi & silvio & governo & elezioni & parlamento & premier & cittadini \\
\hline donne & guardate & centrodestra & renzi & elettorale & presidente & radio & futuro \\
\hline diritto & battista & regione & ministro & votare & riforma & rai & italiani \\
\hline difesa & vedere & lombardia & clandestini & salvini & maggioranza & deputato & vita \\
\hline contro & massima & milano & salvini & marzo & contro & giugno & nessuno \\
\hline ministro & successo & leader & alfano & maggio & deputati & nord & bene \\
\hline
\end{tabular}

PIJ/Volume 5 - Issue 2/2020 
puntOorg

\begin{tabular}{|c|c|c|c|c|c|c|c|}
\hline Topic 9 & Topic 10 & Topic 11 & Topic 12 & Topic 13 & Topic 14 & Topic 15 & Topic 16 \\
\hline Justice and rights & $\begin{array}{c}\text { M5S } \\
\text { Dissemination }\end{array}$ & $\begin{array}{l}\text { Centre-right } \\
\text { coalition }\end{array}$ & Immigration & $\begin{array}{l}\text { Elections and the } \\
\text { League }\end{array}$ & $\begin{array}{c}\text { Central } \\
\text { institutions }\end{array}$ & League media & Politics as hope \\
\hline ordine & verità & maroni & cittadini & campagna & proposta & marzo & dare \\
\hline legge & grillo & sinistra & immigrazione & europee & voto & skytg & democrazia \\
\hline confronti & renzie & candidato & immigrati & simbolo & consiglio & it/dirette-tv & bisogno \\
\hline corte & parole & partito & fedriga & candidati & parlamentari & mercoledì & realtà \\
\hline violenza & sera & regionale & dichiara & matteo & aula & matteo & casa \\
\hline propria & ascoltate & intervista & centinaio & comuni & repubblica & martedì & storia \\
\hline corruzione & condividi & toti & molteni & torino & commissione & venerdì & potere \\
\hline sentenza & italiani & politico & capogruppo & amministrative & diretta & lunedì & politiche \\
\hline reato & giornali & campo & sicurezza & sindaco & decreto & sottosegretario & mesi \\
\hline processo & renzi & coalizione & segretario & buon & fiducia & senatore & vogliamo \\
\hline rispetto & ministro & veneto & casa & regionali & costituzionale & federale & vero \\
\hline diritti & leggi & bene & vergogna & casa & dichiarazione & dicembre & problemi \\
\hline politiche & ospite & elezioni & massimiliano & giugno & elettorale & settembre & davvero \\
\hline magistratura & http://goo.gl & nuovo & deputato & minuti & riforme & agorarai & nuovo \\
\hline vittime & diretta & governatore & profughi & sindaci & senatori & presidente & possibilità \\
\hline pubblica & paola & roma & mare & città & ministri & segretario & passato \\
\hline decisione & post & presidenza & leghista & basilicata & presentato & maggio & rispetto \\
\hline parlamentare & sapere & liguria & pini & nuovo & provvedimento & tgcom & popolo \\
\hline inchiesta & denuncia & elettori & migranti & italiani & stabilità & agorà & capire \\
\hline pena & storia & nazionale & nicola & sardegna & gruppo & europarlamentare & sinistra \\
\hline
\end{tabular}

Table 3.1.1. The 16 topics as characterised by their 30 most important defining words and by inductively developed labels. 
First of all, a basic distinction to be outlined among the topics stems from their nature as either partisan or cross-cutting clusters of communication. A certain topic may immediately appear likely to be the preserve of a single political force, to the extent that its defining inventory of words encompasses the party's main exponents, its territorial bulwarks, some known keywords of its standard communication, etc. On the face of it, eight of the sixteen topics could be characterised as such. The remaining half are conversely marked by more thematic and programmatic undertones, revolving around key issues and cleavages with which I expect most parties to engage.

Of the eight partisan topics, three refer to the League, two to either Berlusconi's party or the centreright coalition, two are associated with the Five Star Movement and one is linked with the Democratic Party.

To begin with, Topic 2 - M5S Participation is identified by the very party name (movement, stars), other known categories of the party discourse (citizens, change, spokesperson, the online platform Rousseau) and also terms related to crowdfunding (contribution, donation, support). Topic 4 - League events corresponds to the public initiatives arranged by Matteo Salvini's party, as it joins the name of the leader with towns (Roma, Milano, Bologna), time markers (tomorrow, Saturday) and gathering occasions (square, meeting, rally, gazebos). Topic 5 - PD Communication includes the names and surnames of Democratic Party leaders (Renzi, Zingaretti, Martina) and other exponents, plus physical venues (festival) and media outlets (such as the magazine Democratica). Topic 8 - FI Communication is the rough counterpart for Forward Italy: alongside the party name, it includes references to several party politicians (Brunetta, Gasparri, Gelmini, Bergamini) and their institutional roles (whip, deputy, senator).

Topic 10 - M5S Dissemination takes up a different side of the Five Star Movement's discourse: insistent recommendations to watch, listen and read information, and then to publicise and share it, are linked to the prime-ministerial deeds of Renzi and framed as matters of truth and denunciation. Topic 11 - Centre-right coalition captures a distinct facet of the communication of Forward Italy's leader Silvio Berlusconi, indeed seeking to maintain or re-establish a centre-right coalition built around his party and capable of winning elections at the national level like at the regional and local ones. Topic 13 - Elections and the League is typically characterised by the presence of electoral vocabulary (vote, elections, campaign, symbol, candidates, to name a few), but League and Salvini are among the top defining words. Finally, Topic 15 - League media complements Topic 4 in that it refers to the 'online' side of the initiatives orchestrated by the party: the omnipresent League and Salvini are accompanied by streaming and hashtag, together with days of the week, months and specific TV programmes.

I now turn to the eight cross-cutting frames. Topic 1 - Government and Economy is dominated by economic terms (employment, taxes, business, billions, economy, fiscal, growth and euro all find room at the top of the list), but the reference to government and budget law is equally clear. In turn, Topic 3 Socioeconomic issues at once includes and expands the economic core of the previous topic by integrating into a single cluster citizenship, income and retirement benefits, workers, families and savers, the government and the banks, parliamentarians and their annuity.

Topic 6 - European Union neatly captures the European axis of party struggle, mainly defined by words such as Europe, European and Brussels but also referring to other countries (France, Russia, Germany) and only residually to terrorism and immigration. Interestingly, Topic 7 - Employment, Schools, Development looks like a progressively inclined topic centred on the very three keywords informing its label, to which territory, culture, infrastructures, youth, research, security, environment and other similar policy domains are added.

Topic 9 -Justice and rights presents itself as a composite topic uniting judicial vocabulary (e.g., State, justice, minister, order, law, court) and the rights and concerns of weaker societal groups (women, right, 
defence, violence, victims) around a common core arguably represented by fairness. Topic 12 Immigration may perhaps have been classified as a partisan frame, inasmuch as the Lega Nord, its political personnel (Fedriga, Molteni, Pini) and their preferred targets (such as the Renzi government and minister Alfano) crucially define it; yet it is also a thematic topic, rooted in the fundamental issue of immigration (including references to immigrants, also and perhaps especially irregular ones).

Topic 14 -Central institutions is a topic entirely described by words that refer to the activities of the Parliament and the government, such as law, Senate, Chamber, government, Parliament, but also president, reform, majority, bill, vote, etc. Finally, the intriguing Topic 16 - Politics as hope seems to take into consideration a more 'day-to-day' aspect of the political realm, grounded in interest in the country, in the State, in possibilities to act for the citizens, the Italians, in ways that are compatible with (a better) future, (a worthy) life, (the common) good, needs (to be satisfied) and democracy.

All in all, while the partisan topics seem to reflect a prevalence of sorts of Salvini's League in the social media sphere, the pool of the programmatic topics remarkably groups several 'usual suspects' - such as immigration and management of the economy - with a few unforeseen but internally consistent themes.

\subsection{Overall diffusion of topics}

A direct look at the relative strength and presence of the 16 topics within the overall Italian political discourse, and thus across the whole of the textual corpora, is offered by Table 3.2.1. For each topic, the table displays two distinct indicators: (i) the average proportion of usage (i.e., the average presence of a given topic within a unit of analysis); (ii) the prevalence proportion (i.e., the proportion of units of analysis whereby the said topic happens to be the most widespread one). Take, for example, Topic 7 - Employment, Schools, Development. The former figure highlights the proportion of the average Facebook post which is taken up by Topic 7, whilst the latter figure displays the proportion of Facebook posts that are composed of words a plurality of which falls under Topic 7.

In principle, discrepancies between the two indicators could point to significant underlying dynamics: for instance, if the second figure were much lower than the first one for Topic 7, such topic would be revealed to work as a filler in texts hegemonised by other topics (Ferri, Lusiani and Pareschi, 2018). For ease of understanding, 'partisan' topics are in green in Table 3.2.1.

\begin{tabular}{|l|l|r|r|}
\cline { 3 - 4 } \multicolumn{2}{c|}{} & Average usage & Most important topic \\
\hline Topic 1 & Government and Economy & $6.1 \%$ & $7.2 \%$ \\
\hline Topic 2 & M5S Participation & $6.2 \%$ & $8.1 \%$ \\
\hline Topic 3 & Socioeconomic issues & $6.0 \%$ & $6.2 \%$ \\
\hline Topic 4 & League events & $6.2 \%$ & $6.8 \%$ \\
\hline Topic 5 & PD Communication & $7.2 \%$ & $10.0 \%$ \\
\hline Topic 6 & European Union & $5.7 \%$ & $5.6 \%$ \\
\hline Topic 7 & Employment & $5.5 \%$ & $4.6 \%$ \\
\hline Topic 8 & Schools & & \\
\hline
\end{tabular}




\begin{tabular}{|c|c|c|c|}
\hline & & Average usage & Most important topic \\
\hline Topic 9 & Justice and rights & $5.6 \%$ & $4.5 \%$ \\
\hline Topic 10 & M5S Dissemination & $6.8 \%$ & $7.9 \%$ \\
\hline Topic 11 & Centre-right coalition & $5.9 \%$ & $5.4 \%$ \\
\hline Topic 12 & Immigration & $6.0 \%$ & $5.8 \%$ \\
\hline Topic 13 & Elections and the League & $5.7 \%$ & $4.5 \%$ \\
\hline Topic 14 & Central institutions & $6.1 \%$ & $5.0 \%$ \\
\hline Topic 15 & League media & $9.0 \%$ & $9.3 \%$ \\
\hline Topic 16 & Politics as hope & $6.7 \%$ & $4.9 \%$ \\
\hline
\end{tabular}

Table 3.2.1. Average proportion of usage and prevalence proportion by topic.

Some considerations can be pointed out. First, no topic appears to enjoy special prominence vis-àvis the others: the ranges of both indicators are decidedly contained, and indeed most topics appear to be conjured with similar frequency. The figures for the average proportion of usage vary from a minimum of 5.3 per cent (Topic 8 - FI Communication) to a maximum of 9.0 per cent (Topic 15 - League media), whereas those for the prevalence proportion vary from a minimum of 4.2 per cent (again Topic 8 - FI Communication) to a maximum of 10.0 per cent (Topic 5 - PD Communication). Second, virtually no topic exhibits a major discrepancy between its two scores. The most eye-catching gap is associated with Topic 5 - PD Communication, whose prevalence proportion (10.0 per cent) surpasses its average proportion of usage (7.2 per cent) by almost three points, whereas the largest difference in the opposite direction is unveiled for Topic 16 - Politics as hope (6.7 per cent versus 4.9 per cent). Given the degree of similarity between the last two columns in Table 3.2.1, the remainder of the article shall only display figures pertaining to one of them, the average proportion of usage.

However, the remarks above should not be interpreted as implying the absence of any deeper trend. When considering the two pools of cross-cutting topics and partisan topics as separate subsets, it can be observed that the combined average proportion of usage of the former amounts to 47.7 per cent, while their combined prevalence proportion amounts to 43.8 per cent. Moreover, for all cross-cutting topics but two the prevalence proportion score is lower than the corresponding average proportion of usage, while the reverse is true for five of the eight partisan topics. Thus, if on the one hand the two subsets enjoy rather similar levels of diffusion within the textual corpora, on the other hand the topics that are most closely related with the style of communication of the individual political parties appear to be slightly more common in terms of their presence, and to have an even less slight edge in terms of their predominance.

\subsection{Overall diffusion of topics by year}

One further aspect worth considering relates to prospective changes in the relevance of the various topics across time, more specifically from one year to another. To probe the magnitude of such variation, I display evidence on the average proportion of usage of each topic by year, rather than over the whole period 2013-2019. For the sake of clarity, two separate graphs plot the respective yearly figures for the cross-cutting topics, then for the partisan topics. 


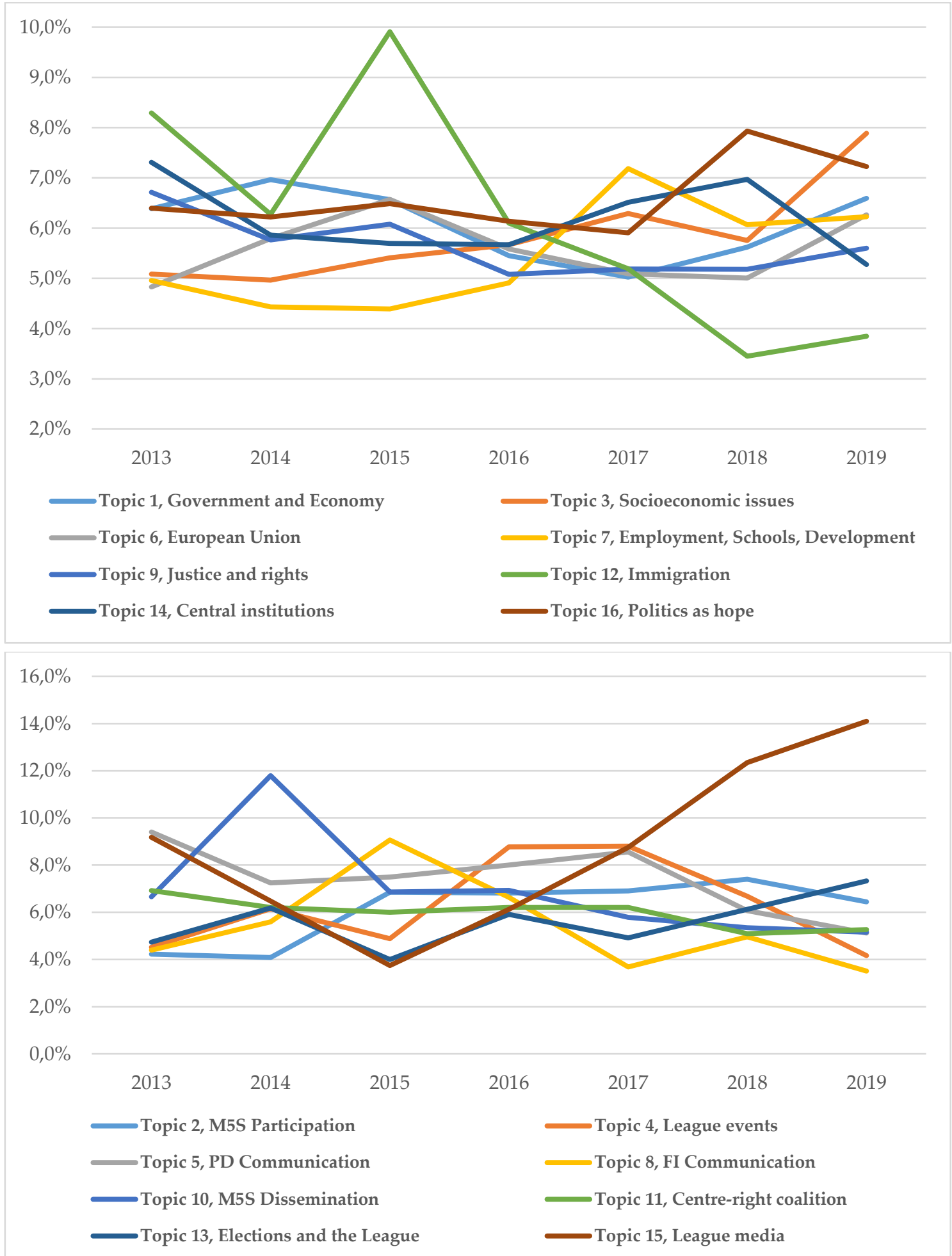

Figure 3.3.1. Average proportion of usage of each topic by year, for cross-cutting and for partisan topics.

Within both the cross-cutting and the partisan pool, the 'rankings' among the eight topics are quite unstable from one year to another. At the same time, the ranges of variation for most topics are quite limited, since almost all yearly figures swing between 4 per cent and 8 per cent. On a yearly basis as well, the partisan topics are confirmed to be slightly more widespread among the textual corpora than the cross-cutting topics: according to data not directly displayed here, the combined average 
proportion of usage of the latter group only reaches the threshold of 50 per cent in years 2013 (exactly 50.0 per cent) and 2015 (51.1 per cent).

As to the individual topics, although it is not possible to dwell on the fluctuations affecting each one, a few points can be made. Among the cross-cutting topics, Topic 7 - Employment, Schools, Development starts from a rather low level in the early years but converges to the mean over time, whereas the presence of Topic 3 -Socioeconomic issues and Topic 16-Politics as hope seemingly grows across time. Most strikingly, after displaying a spike in 2015 presumably in line with a peak of the migrant crisis at the European level, Topic 12 - Immigration appears to wane in 2018-2019. This observation, surprisingly departing from conventional wisdom on the omnipresence of the League's focus on irregular migrants, surely warrants additional scrutiny. As regards the partisan topics, the high figure for Topic 10 - M5S Dissemination in 2014 deserves attention. However, the main story concerns the ascending trend shown ever since 2015 by Topic 15 - League media, which reaches an average proportion of usage of 12.3 per cent in year 2018 and even climbs to 14.1 per cent in year 2019.

\subsection{Party-level analysis: introductory evidence}

As anticipated, I begin my discussion of the outcomes of the text analysis at the party level by providing illustrative evidence in the shape of four word clouds, broadly reflecting the terms that were most frequently employed by each political force. Within each cloud, the size of each word represents its frequency within the textual corpus referring to the corresponding party. The main purpose of Figure 3.4.1 is to familiarise the reader with the messages conveyed by the different political forces, before turning to the findings uncovered via Topic Modelling.
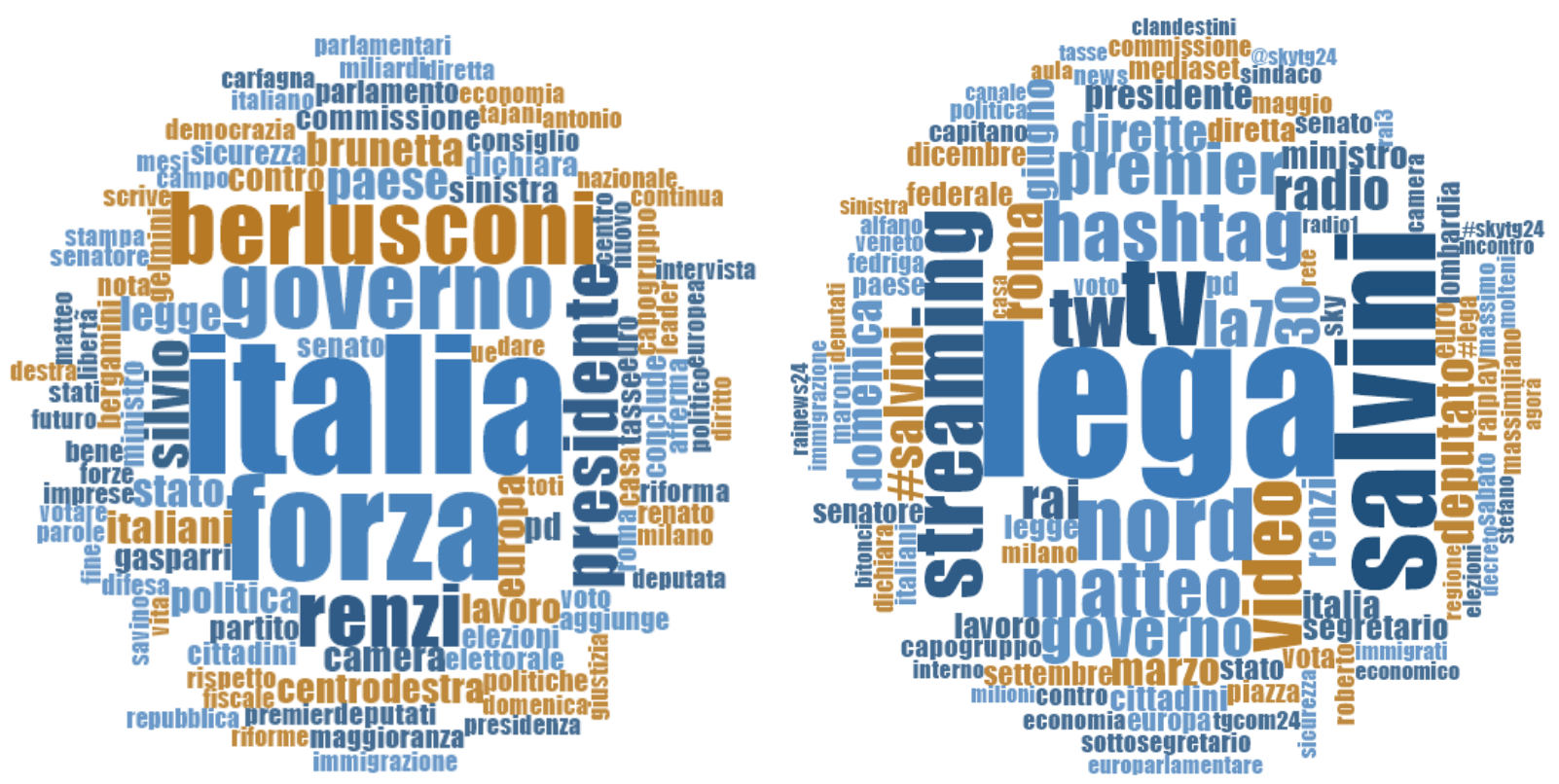

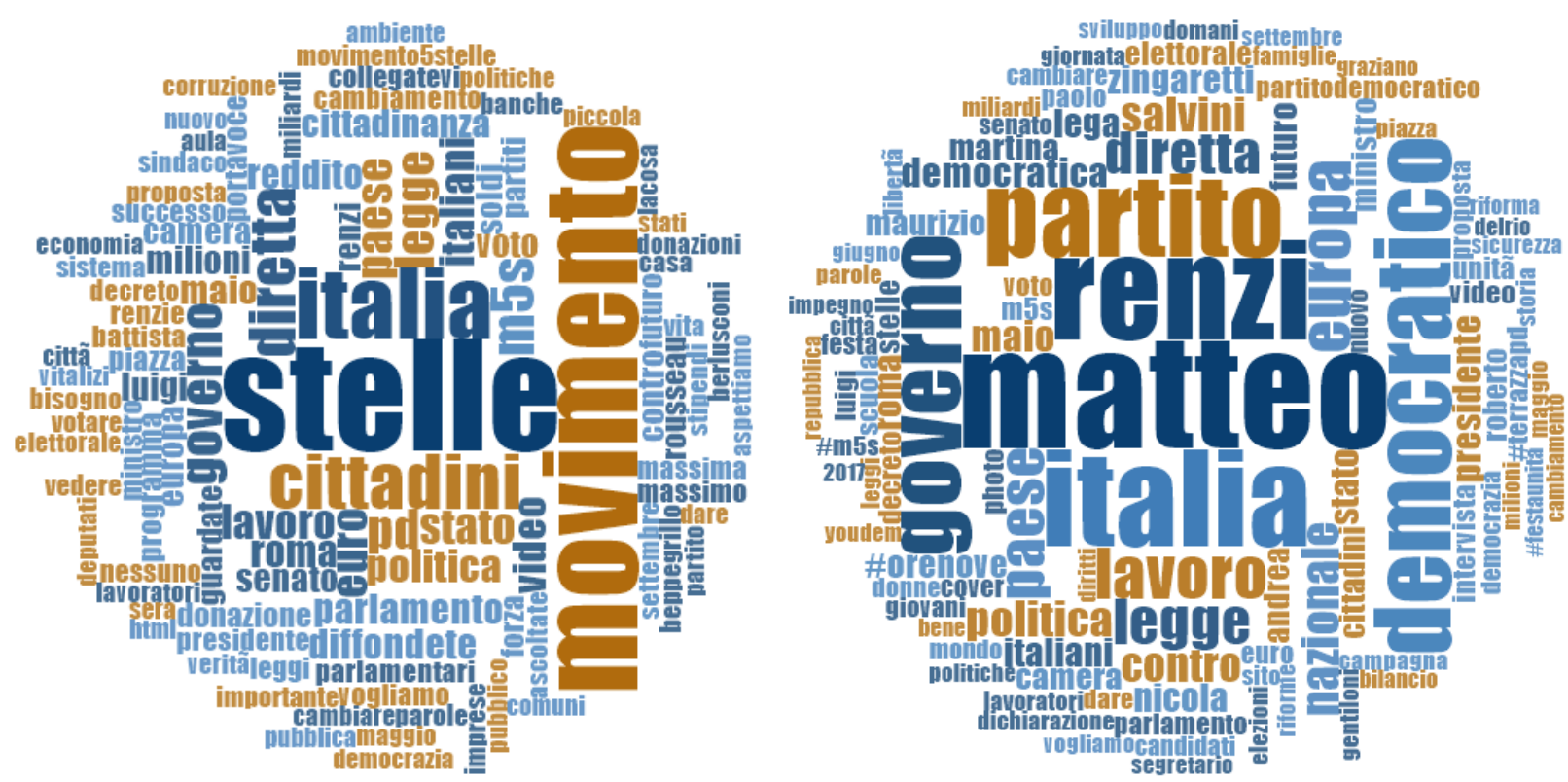

Figure 3.4.1. Word clouds for FI, League, M5S and PD respectively, 2013-2019.

The first cloud stresses how the discourse of Forward Italy in the period 2013-2019 brought to the fore party leader Silvio Berlusconi and a despised opponent, prime minister Matteo Renzi, also referencing institutional politics and party exponents while pushing programmatic language to the outer boundaries of the map. Quite strikingly, but in step with previous remarks, the depiction of the party discourse of the League arising from the second word cloud is one authentically hegemonised by the language of the media, which presumably underscores a penchant for transmedia storytelling. In the word cloud of the Five Star Movement, where many of the words associated with Topic 2 - M5S Participation and Topic 10 - M5S Dissemination are easily spotted, programmatic words such as citizens, employment and law are quite close to the centre as well. Finally, on average over the whole period, the Democratic Party seemed to rely on Matteo Renzi even more than on its own brand; it also mixed strong references to Europe and employment with other ones mentioning the country, evoking political opponents or reflecting the internal life of the party.

\subsection{Parties' recourse to the $\mathbf{1 6}$ topics}

The following Figure 3.5.1 displays a more sophisticated piece of evidence stemming from the Topic Modelling analyses: the average proportion of usage of each topic within each one of the four textual corpora, that is, within the communication of every individual party. By focusing on this, I am able to probe the original distinction between partisan and cross-cutting topic on an empirical basis, before turning to the strength of the linkages that connect each topic to each one of the four main Italian parties. 


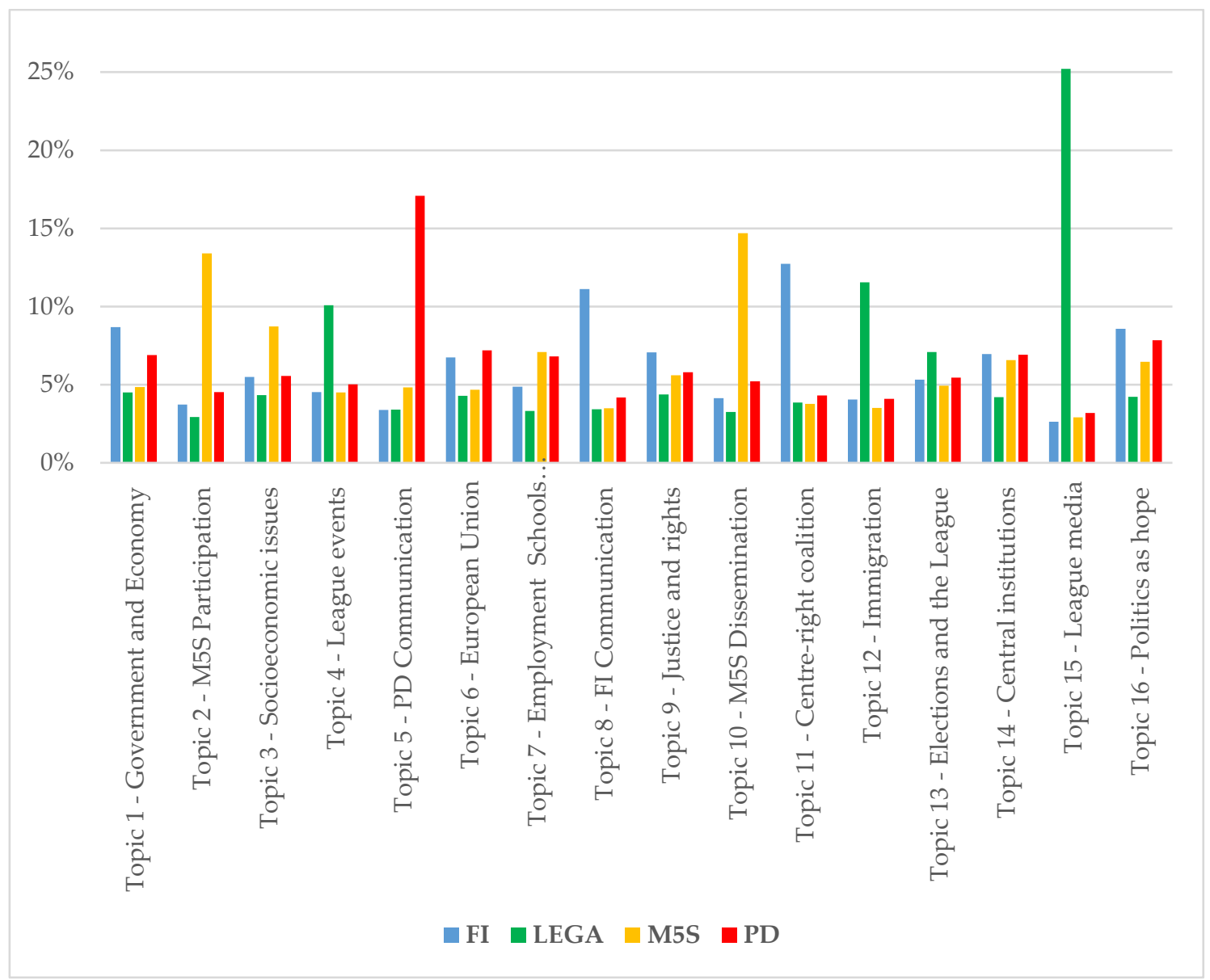

Figure 3.5.1. Average proportion of usage of each topic by party, 2013-2019.

The data in Figure 3.5.1 validate the classification of 'partisan' topics. Virtually every partisan topic is shown to be tightly linked to the communication of a specific party, in accordance with expectations. There is scarce doubt, to begin with, that Topic $2-M 5 S$ Participation and Topic 10-M5S Dissemination are employed by the Five Star Movement much more than by any other party. In a similar way, Topic 8 -FI Communication and Topic 11 - Centre-right coalition are the preferred topics of reference for Forward Italy, the second one even narrowly trumping the first one in terms of frequency. Topic 5 - PD Communication, the single topic associated to the Democratic Party, shows even more sizable an imbalance: on average, the party refers to it in more than 17 per cent of each post. Yet the most one-sided instance is offered by Topic 15 - League media, whose average proportion of usage for the League reaches 25 per cent. Topic 4 -League events is also in line with the initial expectation. Only Topic 13 - Elections and the League appears in the League's Facebook posts marginally more than in the other parties' ones. Therefore, the topic is revealed to be primarily a cluster of words about elections and voting, which is exploited - but not essentially so - by Salvini's party.

As regards the topics I have described as cross-cutting, I note what follows. Topic 1 - Government and Economy is mainly employed by FI and PD, the two parties of the centre-right and the centreleft, presumably having engaged in 'valence politics' (Stokes, 1963) by giving opposite evaluations of the performance of the Renzi Cabinet (2014-2016) in managing the economy. Topic 3 Socioeconomic issues appears to characterise M5S somewhat more than the other parties: the overall hue of the topic chimes well enough with some of the more 'loaded' words inside the party's cloud. Topic 6 - European Union is surprisingly used by PD and FI more than by the parties having most 
vocally challenged the European level, the League and M5S, albeit the differences are not massive. Topic 7 -Employment, Schools, Development is mainly employed by M5S (7.1 per cent) and PD (6.8 per cent), probably due to its progressive inspiration.

Topic 9 - Justice and Rights reveals no clear party prevalence: the different parties probably employ it in different manners, and the attention paid by FI to it may be explained with reference to Berlusconi's recurring trouble with the law. Topic 12 - Immigration is the thematic topic showing the greatest imbalance in average usage between a single party, the League (11.5 per cent), and the rest. Topic 14 - Central institutions, conveying the language of institutional politics, visibly surfaces in the language of all parties - again probably with different connotations - minus the League. Finally, Topic 16 - Politics as hope somewhat counterintuitively marks the party discourse of FI slightly more than either PD or M5S, which arguably testifies to a certain rhetorical vagueness surrounding the topic itself.

In order to capture more directly the respective strength of the different topics within the flows of communication of the individual political parties, I now turn to Figure 3.5.2. The figure contains the same information exhibited in Figure 3, yet it groups the parties' average proportions of usage of the different topics by party rather than by topic, thus providing an overview of the mélange of topics within each party's discursive menu.

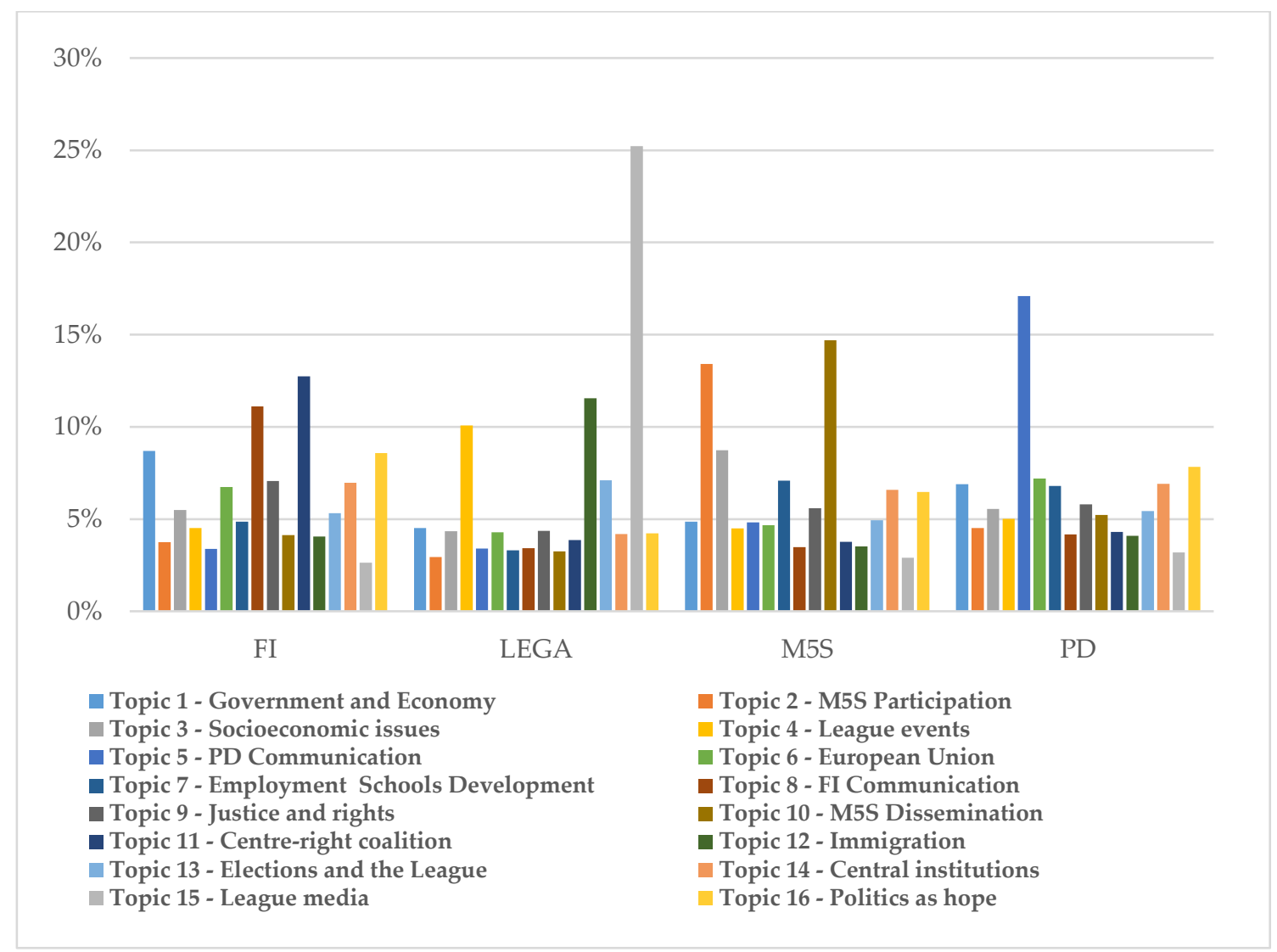

Figure 3.5.2. Average proportion of usage of each topic by party, 2013-2019.

As can be seen, the party discourse of FI is centred on Topic 11 - Centre-right coalition (12.7 per cent) and Topic 8 - FI Communication (11.1 per cent). The most frequent cross-cutting topics are Topic $1-$ Government and Economy (8.7 per cent) and Topic 16 - Politics as hope (8.6 per cent), followed by Topic 
9 - Justice and rights (7.1 per cent), Topic 14 - Central institutions (7.0 per cent) and Topic 6 - European Union (6.7 per cent).

In contrast, the discourse of the League unfolds in much more polarised ways: as many as 12 topics out of 16 do not reach the threshold of 5 per cent. Three out of the four main ingredients that hold sway are partisan topics, namely Topic 15 - League media (25.2 per cent), Topic 4 - League events (10.1 per cent) and Topic 13 -Elections and the League (7.1 per cent); the only cross-cutting exception, Topic 12 - Immigration, conquers second place with 11.5 per cent.

As to the M5S, predominance is again exhibited by the two partisan topics, namely Topic $10-M 5 S$ Dissemination (14.7 per cent) and Topic 2 - M5S Participation (13.4 per cent). Still, the threshold of 5 per cent is also clearly exceeded by some of the thematic topics: the progressive Topic 3 Socioeconomic issues (8.7 per cent) and Topic 7 - Employment, Schools, Development (7.1 per cent), plus Topic 14 - Central institutions (6.6 per cent) and Topic 16 - Politics as hope (6.5 per cent).

Finally, the somewhat similar configuration of topics related to the PD accentuates the tendency to discuss almost every topic while concentrating on almost none. As a matter of fact, much below the clearly dominant Topic 5 - PD Communication (17.1 per cent) I find a handful of cross-cutting clusters including Topic 16 - Politics as hope (7.8 per cent), Topic 6 - European Union (7.2 per cent), Topic 1 Government and Economy (6.9 per cent),Topic 14 - Central institutions (6.9 per cent) and Topic 7 Employment, Schools, Development (6.8 per cent). Five more topics display an average proportion of usage which is at least equal to 5 per cent.

\section{Conclusions}

The instability of the Italian political system during the 'critical juncture' of the last few years, when the impact of the sovereign debt crisis and of the migrant crisis have compounded pre-existing predicaments, has borne heavily upon the party system by injecting into it exceptional levels of electoral volatility. To be sure, the ebb and flow in the mass support respectively enjoyed by the main parties is a visible manifestation of the struggles that have taken place among those political forces within and through the sphere of political discourse. Therefore, it is both timely and relevant to study the discourse of the Italian parties over the recent years. This article has set out to explore the topics that prevailingly characterised the streams of communication released by such parties, innovatively focusing on the Facebook posts they published between 2013 and 2019 and analysing them through the Topic Modelling technique.

All in all, the overall configuration of the discourse of political parties in Italy is aptly described by a model including as many as 16 topics, equally divided into two types. A first group of eight partisan topics, heavily linked to the style of communication of individual parties, comprises topics labelled as follows: M5S Participation, League events, PD Communication, FI Communication, M5S Dissemination, Centre-right coalition, Elections and the League, League media. A second group of eight cross-cutting topics, mostly having a thematic and programmatic nature, is composed of the following ones: Government and Economy, Socioeconomic issues, European Union, Employment Schools Development, Justice and rights, Immigration, Central institutions, Politics as hope. Remarkably, alongside well-known bones of contention such as the European question, immigration and management of the economy, the pool of cross-cutting topics includes a few themes whose identification is surely less foregone. In terms of their diffusion, all the 16 topics appear within the whole of the gathered textual data with roughly comparable frequency, insofar as their average proportion of usage ranges 
- with one exception - between 5.3 per cent and 7.2 per cent. At the same time, the partisan subset of topics has been found to exert a slightly stronger overall presence than the cross-cutting subset.

Shifting to the party level, the analysis has unsurprisingly revealed the League to have acquired a kind of prominence in the social media sphere, not least by virtue of the three partisan topics related either strongly (League media, League events) or weakly (Elections and the League) to Salvini's party. More generally, each individual political force has been shown to display a party discourse primarily connoted by recourse to the partisan topic(s) enshrining its baseline style of communication, with emphasis on issues, programmes and policy domains coming second. By and large, the patterns of association between the various parties and the 16 topics identified via Topic Modelling have not contradicted the expectations that could have been laid out beforehand, thus confirming the 'construct validity' of the selected topic model. It is also worth noting that the four parties differ among themselves not just in terms of the topics they invested in, but also in terms of the extent to which they chose to focus on a few targeted topics, as opposed to a more comprehensive discourse comprising several topics with more diluted frequencies. The first polar type is neatly exemplified by the League, forcefully adding Immigration to its three partisan topics. Conversely, the PD comes closest to the opposite polar type, combining references to Politics as hope, European Union, Government and Economy, Central institutions, Employment Schools Development, and a few more.

Some of the results discussed above can straightforwardly be listed among the main upshots of this work. Firstly, the inductively developed conceptual distinction between partisan topics and crosscutting topics appears to configure a useful analytical tool to evaluate balances and imbalances, within the overall political discourse and the communication of specific parties. Secondly, recourse to Topic Modelling provides a peculiar angle to the identification of the policy issues which are particularly salient in the statements of political parties at a given time: an approach which gains face validity through the presence of topics such as Government and Economy, European Union and Immigration. At the same time, the discovery of two separate topics connected with socioeconomic development - Socioeconomic issues and Employment Schools Development, to which one may even add Government and Economy - prompts to remember the enduring importance of such matters in Italian politics. Thirdly, the identification of different party approaches to the configuration of the menu of topics to be invoked begs the question of whether any particular strategy may be endowed with clearer effectiveness over the others, or whether different strategies may be effective for different types of parties.

Precisely in view of its explorative nature, anyway, the present study is characterised by some limitations, which have been noted and discussed within the article. With reference to data gathering, it is imperative to resist the temptation to equate the textual corpora I have analysed with 'Italian party discourse in 2013-2019'. First, while only the four major parties of that period have been taken into consideration, other minor parties may be argued to have played a non-negligible part in the public debate. Second, the streams of party communication that flow through Facebook pages should ideally be complemented with other sources of discursive data - from the fan pages of the corresponding party leaders, to electoral manifestos, party communiqués, parliamentary debates, and so on and so forth - in order to ensure triangulation (see again Bottos, Desiata and Pareschi, 2020). Third, while the data collection strategy is innovative and fits the research purpose, I have shown the dataset itself to be less than perfect.

Some caveats also exist in relation to the stage of data analysis. To begin with, Topic Modelling is not equipped to factor in either pictures, videos or external content accessible through hyperlinks. Moreover, the iterative, inductive and prevailingly qualitative approach to the identification of the most appropriate topic model and to the interpretation of the topics incurs inevitable, well-known 
pitfalls. To allay such concerns, however, I have grounded research decision in criteria soundly specified ex ante and designed a form of 'inter-coder reliability' test, whose outcomes have been more than reassuring. More generally, all methodological choices have been elucidated, conveying scientific rigour through careful engagement in "description of the [...] procedures which would make a Popperian exercise of refutation possible" (Gaxie and Rowell, 2011: 44).

In any case, it can be contended that many of the imperfections recalled above actually point to steps to be taken in following efforts. To begin with, triangulation could be effectively pursued by means of the inclusion of at least some of the mentioned alternative sources of data on party discourse. Moreover, minor parties deemed to have brought significant contributions to the overall political discourse could also be included. To be sure, the researcher should very carefully weigh up the most appropriate ways to combine these additional sources into a single textual dataset expressly designed to reflect the Italian political discourse faithfully and comprehensively. Apart from data collection aspects, the versatile technique of Topic Modelling can be made to travel to different countries and their respective political parties, precisely because of its capacity to combine automated processing of large textual corpora with an inductive perspective on the best-suited signification of different iterations. This move would pave the way for cross-country and cross-party comparison, also allowing for explanatory studies that could seek to connect the presence of certain topics, and actual reliance on them, to the specific characteristics of the said countries and parties.

\section{Keywords}

Italian politics; party discourse; content analysis; text analysis; topic modelling; social media; Facebook

\section{Reference list}

Behar Villegas, E. (2016), “Facebook and its Disappearing Posts: Data Collection Approaches on FanPages for Social Scientists", The Journal of Social Media in Society, 5 (1): 160-188.

Blei, D.M., Ng, A.Y., and Jordan, M.I. (2003), "Latent Dirichlet Allocation”, Journal of Machine Learning Research, 3 (1): 993-1022.

Bottos, G., Desiata, E., and Pareschi, A. (2020), “Introduction: On Discourse Categories and Their Political Use: Conceptual and Methodological Foundations of the Study", in G. Bottos, E. Desiata and A. Pareschi (eds), Changing Political Discourse in the Aftermath of the 2008 Crisis: The Case of Italy, 11-48, Brussels/Rome: FEPS and Fondazione Gramsci.

Budge, I., and Farlie, D. (1983), Explaining and Predicting Elections: Issue Effects and Party Strategies in Twenty-Three Democracies, London: Allen and Unwin.

Chong, D., and Druckman, J. (2007), "Framing Theory", Annual Review of Political Science, 10: 103126.

Dalton, R. (1985), “Political Parties and Political Representation: Party Supporters and Party Elites in Nine Nations", Comparative Political Studies, 18 (3): 267-299.

DiMaggio, P., Nag, M., and Blei, D. (2013), “Exploiting Affinities between Topic Modeling and the Sociological Perspective on Culture: Application to Newspaper Coverage of U.S. Government Arts Funding", Poetics, 41 (6): 570-606.

Disch, L. (2011), “Towards a Mobilization Conception of Democratic Representation", The American Political Science Review, 105 (1): 100-114. 
Downs, A. (1957), An Economic Theory of Democracy, New York, NY: HarperCollins.

Ernst, N., Engesser, S., Büchel, F., Blassnig, S., and Esser, F. (2017), “Extreme Parties and Populism: An Analysis of Facebook and Twitter across Six Countries", Information, Communication $\mathcal{E}$ Society, 20 (9): 1347-1364.

Ferri, P., Lusiani, M., and Pareschi, L. (2018) “Accounting for Accounting History: A topic modeling approach (1996-2015)", Accounting History, 23 (1-2): 173-205.

Gaxie, D., and Rowell, J. (2011), "Methodology of the Project", in D. Gaxie, N. Hubé and J. Rowell (eds), Perceptions of Europe: A Comparative Sociology of European Attitudes, 37-49, Colchester: ECPR Press.

Gurevitch, M., and Levy, M.R. (eds, 1985), Mass Communication Review Yearbook (Vol. 5), Beverly Hills, CA: SAGE.

Hoeglinger, D. (2016), "The Politicisation of European Integration in Domestic Election Campaigns", West European Politics, 39 (1): 44-63.

Hannigan, T., Haans, R.F.J., Vakili, K., Tchalian, H., Glaser, V., Wang, M., Kaplan, S., and Devereaux Jennings, P. (2019), “Topic Modeling in Management Research: Rendering New Theory from Textual Data", Academy of Management Annals, 13 (2): 586-632.

McCallum, A.K. (2002), “MALLET: A Machine Learning for Language Toolkit”. Available online at http://mallet.cs.umass.edu (last accessed: February 26, 2020).

Mohr, J.W., and Bogdanov, P. (2013), "Introduction: Topic Models: What They Are and Why They Matter", Poetics, 41 (6): 545-569.

Mosca, L., and Tronconi, F. (2019), “Beyond Left and Right: The Eclectic Populism of the Five Star Movement", West European Politics, 42 (6): 1258-1283.

Passarelli, G., and Tuorto, D. (2018), La Lega di Salvini: Estrema Destra di Governo, Bologna: Il Mulino.

Petrocik, J.R. (1996), "Issue Ownership in Presidential Elections, with a 1980 Case Study", American Journal of Political Science, 40 (3): 825-850.

Rieder, B. (2013), "Studying Facebook via Data Extraction: The Netvizz Application", in H. Davis et al. (eds), WebSci '13: Proceedings of the $5^{\text {th }}$ Annual ACM Web Science Conference, 346-355, New York, NY: Association for Computing Machinery. Available online at https://dl.acm.org/doi/proceedings/10.1145/2464464 (last accessed: February 26, 2020).

Rohrschneider, R., and Whitefield, S. (2012), The Strain of Representation: How Parties Represent Diverse Voters in Western and Eastern Europe, Oxford: Oxford University Press.

Rovny, J. (2012), "Who Emphasizes and Who Blurs? Party Strategies in Multidimensional Competition", European Union Politics, 13 (2): 269-292.

Sartori, G. (1976), Parties and Party Systems, Cambridge: Cambridge University Press.

Stokes, D.E. (1963), "Spatial Models of Party Competition", The American Political Science Review, 57 (2): 368-377. 